\title{
IMPACT OF PLASTIC DEFORMATION ON THE PROPERTIES OF A SELECTED ALUMINIUM ALLOY
}

\author{
Anna LišKová*, Petra Lacková, Mária Mihaliková, Robert KočišKo \\ Institute of Materials, Faculty of Metallurgy, Technical University of Košice, Slovakia \\ * corresponding author: anna.liskova@tuke.sk
}

ABSTRACT. This paper reports on an experiment to assess the influence of plastic deformation on the microstructure and properties of EN AW $6012(\mathrm{AlMgSiPb})$ aluminium alloy in two states. The first was the initial state with heat treatment T3, and the second was the state after intensive plastic deformation by ECAP (Equal Channel Angular Pressing) technology. The ECAP process was carried out repeatedly at room temperature. In the initial state of the alloy, the process redistributed eutectic Si-particles and increased the strength of the alloy. The mechanical properties and the hardness increased due to intensive plastic deformation (the yield strength increased by $15 \%$, the tensile strength by $6 \%$, and the hardness by $23 \%$ ). The fracture cracks initiated and propagated mainly along eutectic particles. The fracture area of the ECAPed specimen displayed a typical ductile cavity characteristic.

KEYwORDS: intensive plastic deformation; aluminium alloy; tensile test.

\section{INTRODUCTION}

The AlMgSiPb alloy investigated here belongs to the AA6xxx (AlMgSi) series of aluminium alloys, where magnesium and silicon are the principal alloying elements. Commercial alloys of this type contain mass fractions of $0.5 \%$ to $1.5 \%$ of $\mathrm{Si}$ and $0.5 \%$ to $1.5 \%$ of $\mathrm{Mg}$, and are used in great quantities. They are universal aluminium alloys which can be extruded into sections, rods and tubes. Their characteristics are a high level of workability, strength properties, corrosion resistance and machinability. Their mechanical and technological properties depend on the chemical composition and the heat treatment of the castings, i.e., cast blanks and extruded pieces [1, 2]. Free machining aluminium alloys are well known in the literature [3, 4. These alloys typically include free machining constituents that are insoluble but soft and nonabrasive. They are beneficial, assisting in chip breakage and tool life [3]. More specifically, at the point of contact between the tool and the material, softening and melting occur. As a result of these changes, breakage occurs, chips are formed and material removal is enhanced. It is well known that chip breaking is promoted by the addition of $\mathrm{Pb}$ to conventional aluminium alloys, since $\mathrm{Pb}$ has poor solubility in solid aluminium and forms a soft, low melting point phase [5, 6].

Apart from the major alloying elements, standard aluminium alloys for free cutting also include additions (lead, bismuth), which form softer phases in the matrix. These "free machining" phases improve the machinability of the alloys, because the chips break more easily, they have a smooth surface, lower cutting forces and cause less tool wear. Since lead is poisonous, there is a tendency to replace it with other elements: tin and, to some extent, indium are the most frequently-used substituents.

Alloys with tin must have similar or better prop- erties than standard alloys as regard microstructure, workability, mechanical properties, corrosion resistance, and machinability [7. In recent time, tin has been added mainly to Al-Mg-Si (AA 6000 series) alloys and to $\mathrm{Al}-\mathrm{Cu}$ (AA 2000 series) alloys, which normally contain lead and bismuth, or only lead. Semi-finished products made from these alloys in the form of bars are used for free cutting or, more precisely, for turning [8]10]. Equal-Channel Angular Pressing (ECAP) is a very useful method for producing ultra-fine microstructures of Al-based alloys with significantly improved mechanical properties [11-16]. During the last two decades, intensive plastic deformation (SPD) techniques have been widely applied to obtain an ultrafine-grained (UFG) structure, which can significantly improve the mechanical properties of $\mathrm{Al}-\mathrm{Mg}-\mathrm{Si}$ alloys [17, 18. Among various SPD techniques, equal channel angular pressing (ECAP) is the most promising method for fabricating large bulk UFG materials [19, 20]. A significant increase in strength is obtained during ECAP processing [21]. In addition, some ultrafine- grained Al-based alloys produced by the ECAP procedure have shown a superplastic forming capability [16]. Intensive plastic deformation by the ECAP process also significantly increases the density of lattice defects in a solid solution of Al-based alloy, and can therefore accelerate the precipitation process of strengthening particles during the post-ECAP ageing treatment applied to an age-hardenable alloy 22 24. Al-Mg-Si alloys can be strengthened by precipitation hardening. It is essential to study the precipitation sequence and the precipitation behavior. The precipitation sequence in $\mathrm{Al}-\mathrm{Mg}-\mathrm{Si}$ alloy is

$$
\text { atomic clusters } \rightarrow \text { GP zones } \rightarrow \beta^{\prime \prime} \rightarrow \beta^{\prime} \rightarrow \beta,
$$

where the atomic clusters are the supersaturated solid solution; GP zones are generally spherical clus- 


\begin{tabular}{cccccccc}
\hline $\mathrm{Si}$ & $\mathrm{Fe}$ & $\mathrm{Mn}$ & $\mathrm{Mg}$ & $\mathrm{Cr}$ & $\mathrm{Bi}$ & $\mathrm{Pb}$ & $\mathrm{Al}$ \\
\hline 1.13 & 0.37 & 0.53 & 0.83 & 0.2 & 0.51 & 0.83 & bal. \\
\hline
\end{tabular}

TABLE 1. The chemical composition of AW 6012 [wt.\%].

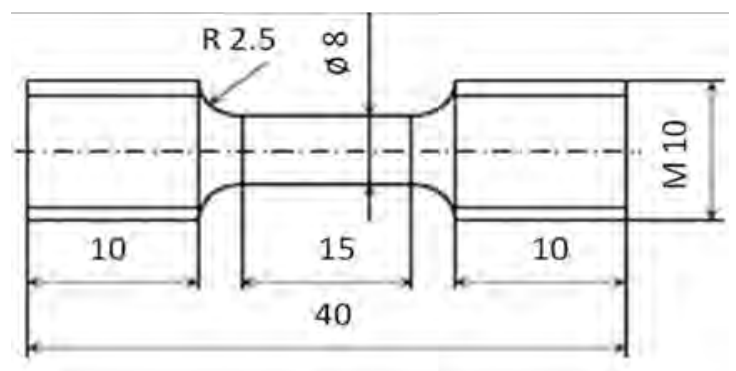

FIGURE 1. The shape and the parameters of the short specimen for the tensile test.

ters with unknown structure; $\beta^{\prime \prime}$ precipitates are fine needle-shaped zones with a monoclinic structure. They are generally present in $\mathrm{Al}$ alloys aged to maximum hardness; $\beta^{\prime}$ are rod-shaped precipitates with a hexagonal structure and are found in overegged specimens; $\beta\left(\mathrm{Mg}_{2} \mathrm{Si}\right)$ is an equilibrium phase in the precipitation sequence. Among these, the $\beta^{\prime \prime}$ phases are considered to make the main contribution to strength. The significant improvement in the strength of $\mathrm{Al}$ alloy upon SPD is due to the dynamic ageing effect, as reported in earlier work. The strength and the ductility of an $\mathrm{Al}$ alloy were further improved by static ageing [25].

Our study has been aimed at understanding the influence of the ECAP process on the microstructure and the mechanical properties of AlSiMgPb alloys.

\section{MATERIAL AND METHODS}

EN AW 6012 aluminium alloy on the basis of AlMgSiPb was used as the experimental material. In the initial state, the experimental material was treated with T3 - solution annealing and natural ageing. Prior to deformation in an ECAP die, the specimens of the initial states were solution annealed for $1.5 \mathrm{~h}$ at $550^{\circ} \mathrm{C}$. The alloy was then subjected to intensive plastic deformation by heat treatment: the solution was annealed for $1.5 \mathrm{~h}$ at $550{ }^{\circ} \mathrm{C}$, followed by 4 passes of ECAP and artificial ageing for $30 \mathrm{~h}$ at $100^{\circ} \mathrm{C}$. The ECAP process was performed in a die with the following parameters: channel intersection angle $\Phi=90^{\circ}$, and arc of curvature $\Psi=37^{\circ}$. Repetitive pressing of specimens $\varnothing 10 \mathrm{~mm} \times 80 \mathrm{~mm}$ in size was attempted in the ECAP die at room temperature, using the $B_{C}$ route (the sample was rotated in direction by $90^{\circ}$ ). The chemical composition of the aluminium alloy is shown in Table 1. Figure 1 shows the parameters of the specimens that were used for the tensile test.

Microstructures were prepared by standard metallographic methods (special enhanced etching - etchant:

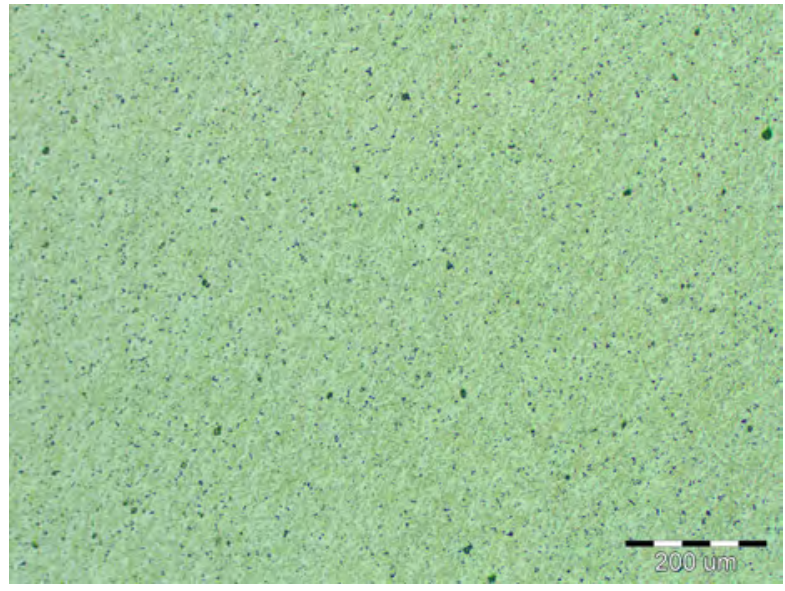

FiguRE 2. Microstructure of the aluminium alloy in the initial state.

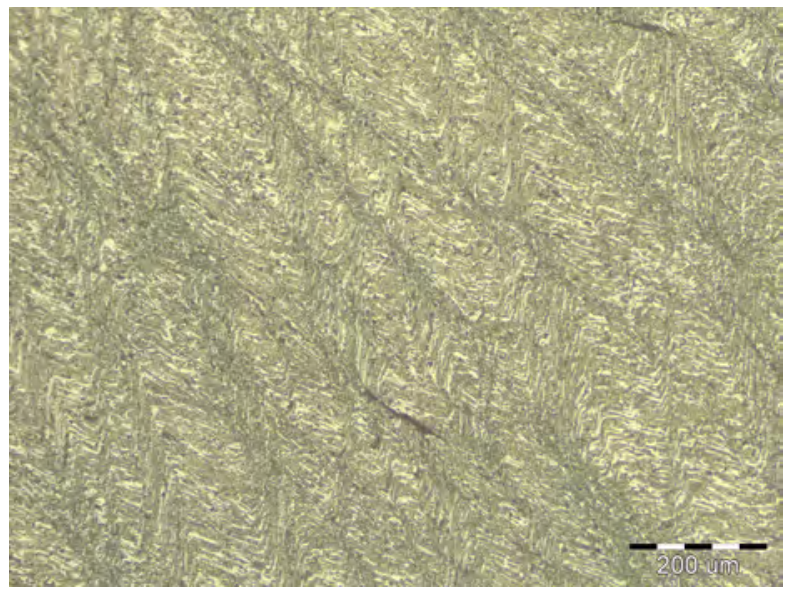

FigURE 3. Microstructure of the aluminium alloy after ECAP and heat treatment.

modified Kroll - 92ml distilled water, $6 \mathrm{ml} \mathrm{HNO}_{3}$, and $2 \mathrm{ml} \mathrm{HF}$ ) and were observed using an OLYMPUS optical microscope. The fracture surfaces were studied by means of a Scanning electron microscope (a JEOL model JSM 7000F microscope operated at an accelerating voltage of $300 \mathrm{kV}$ ). Particle identification was carried out using EDX quantitative analysis with the INCA-sight analyser.

The influence of severe plastic deformation by the ECAP process and post-ECAP artificial ageing on the mechanical properties of the analyzed alloys was evaluated with a Vickers hardness measurement (HV 10) and a tensile test. The hardness was estimated in a cross-section by the Vickers test with a dwell time of 10s. The test was carried out according to the EN ISO 6507-1 standard [26. The hardness was estimated in a cross-section. The pre-ECAP and post-ECAP state of the samples was evaluated by 10 measurements in 2 lines. For the Vickers test, a very small diamond indenter with pyramidal geometry is forced into the surface of a specimen of $\mathrm{AlMgSiPb}$ aluminium alloy [27].

The mechanical properties (yield strength - YS, ultimate tensile strength - UTS, elongation - A, and 

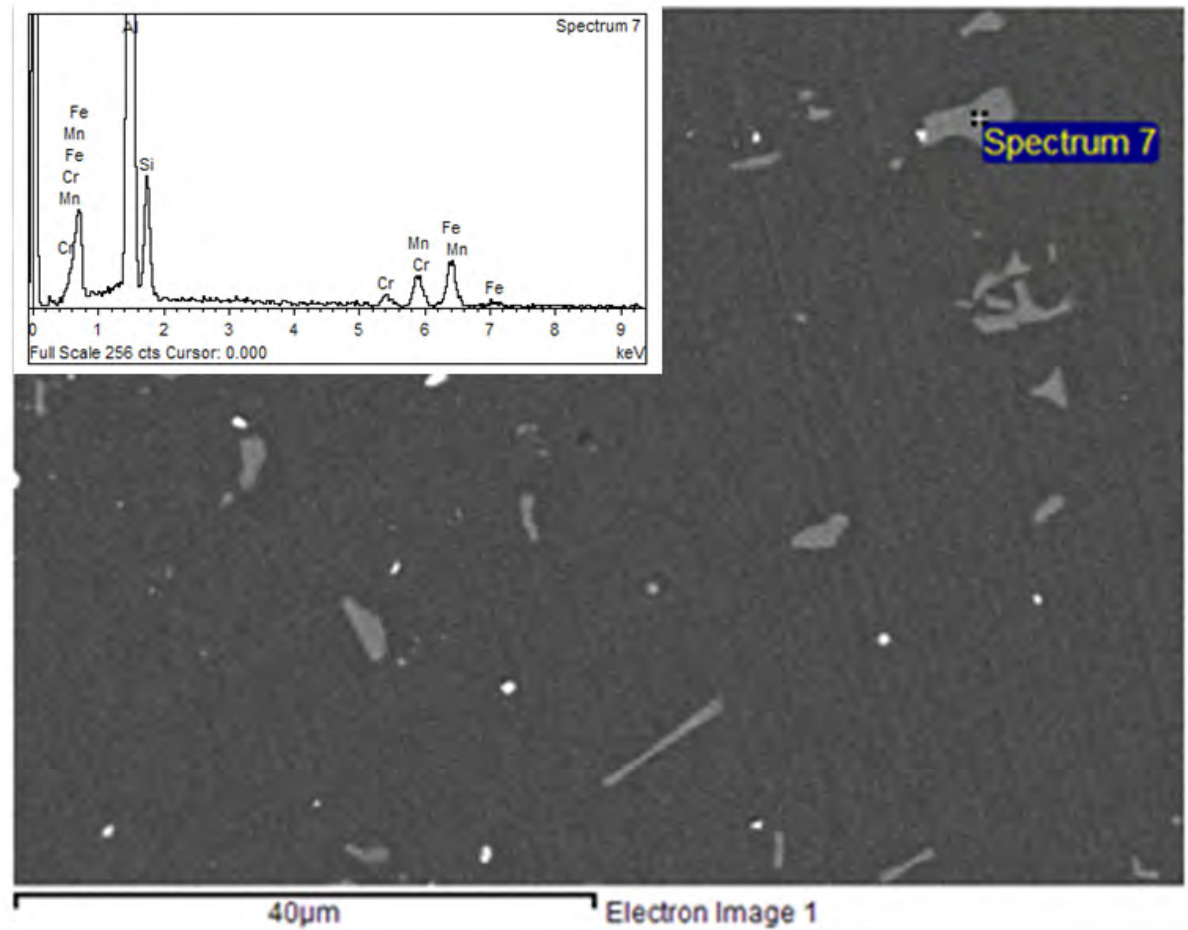

Figure 4. The EDX analysis of the aluminium alloy in the initial state.

reduction of area - Z) were measured by a uniaxial tensile test carried out using a ZWICK 1387 machine, according to STN EN ISO 6892-1 28, for samples $8 \mathrm{~mm}$ in diameter (Figure 1). The tension test can be used to ascertain several mechanical properties of materials that are important in mechanical engineering. The tensile test (the initial strain rate of $2.5 \cdot 10^{-4} \mathrm{~s}^{-1}$ ) was carried out on specimens made from quenched, ECAP-processed and post-ECAP specimens. The tensile testing machine is designed to elongate the specimen at a constate rate using an extensometer [27, 29. The Young modulus was measured using a WN2 52497 extensometer. A LEICA WILD M 32 microscope was used to observe the macrostructure after a tensile test had been applied.

\section{Results And Discussions}

The microstructure (Figure 2 characteristics of the initial state of the investigated alloy, its state after quenching (Figure 3), deformation in the ECAP die and subsequent ageing treatment were analyzed in the central zone of the cross-section of the specimens. Figure 3 shows the ultrafine-grained (UFG) structure with nearly equi-axial morphology, where we can observe the locations of elongated grains. Figure 3 shows the deformed microstructure after intensive plastic deformation with characteristic shear bands along the cross section of the sample. The heterogeneous microstructure of the ECAP-ed alloy indicates a non-uniform deformation along the cross-section of the ECAP-ed specimen. The shear bands are well developed in alloys after plastic deformation, and can be clearly distinguished from the other regions of the microstructure under an optical microscope (Figure 3).

Figure 4 shows the spectrum of the aluminium alloy in the pre-ECAP state, and Figure 5 shows the spectrum of the alloy in the post-ECAP state. It consists of a primary phase a-Al solid solution, which forms the matrix of the material, and secondary phases distributed at the grain boundary and in the interdendritic regions. The secondary constituents, such as $\mathrm{Mg}_{2} \mathrm{Si}$ and $\alpha-\mathrm{Al}(\mathrm{FeMn}) \mathrm{Si}$ compounds, as revealed by EDS, are clustered in bands oriented parallel to the extrusion direction. The $\alpha-\mathrm{Al}(\mathrm{FeMn}) \mathrm{Si}$ phase is also present as coarse particles. When the billets were heat treated, the grain segregations and the coarse $\mathrm{Mg}_{2} \mathrm{Si}$ particles in the a-Al matrix dissolved. The maximum number of $\mathrm{Mg}$ and $\mathrm{Si}$ atoms in the alloy are therefore in a solid solution in the extruded section, and are therefore available for precipitating the hardening particles during ageing. Coarse $\mathrm{Mg}_{2} \mathrm{Si}$ particles present in the microstructure do not help to strengthen the alloy. Coarse Mn and Cr phases, detected by EDX analyses, are distributed mainly along the grain boundaries. Large $\mathrm{Pb}$ bearing particles are normally found adjacent to Fe particles, and sometimes enveloping them [30].

The mechanical properties were evaluated by a static tensile test at room temperature. The dependent force of strain and elongation in static condition is shown in Figure 6. The specimen is deformed, usually to fracture, with a gradually increasing tensile load that is applied uniaxially along the long axis of the specimen. The results for mechanical properties, 


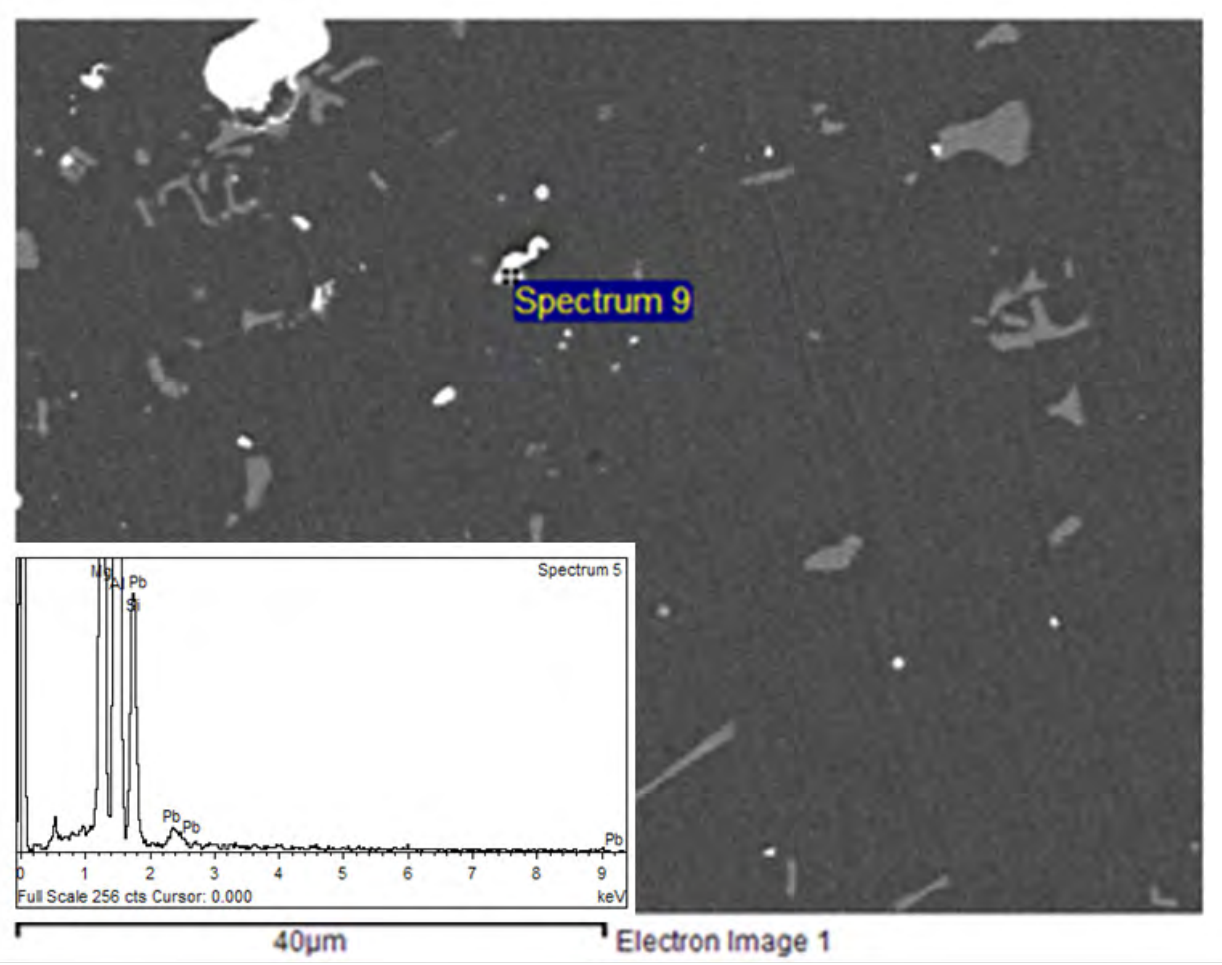

Figure 5. The EDX analysis of the aluminium alloy after ECAP and heat treatment.

\begin{tabular}{lcccccc}
\hline State & $\begin{array}{c}\text { YS } \\
{[\mathrm{MPa}]}\end{array}$ & $\begin{array}{c}\text { UTS } \\
{[\mathrm{MPa}]}\end{array}$ & $\begin{array}{c}\text { A } \\
{[\%]}\end{array}$ & $\begin{array}{c}\text { Z } \\
{[\%]}\end{array}$ & $\begin{array}{c}\text { E } \\
{[\mathrm{GPa}]}\end{array}$ & HV10 \\
\hline Initial & 309 & 350 & 17 & 23 & 75 & 103 \\
ECAPed & 355 & 372 & 10 & 8 & 70 & 125 \\
\hline
\end{tabular}

TABLE 2. Mechanical properties of the investigated aluminium alloy.

evaluated as average values from six measurements, are summarized in Table 2 The intensive plastic deformation realized by ECAP technology increased the yield strength properties from $309 \mathrm{MPa}$ to $355 \mathrm{MPa}$, and the ultimate tensile strength from $350 \mathrm{MPa}$ to $372 \mathrm{MPa}$. However, the values for the plastic characteristics decreased. The elongation value decreased from $17 \%$ to $10 \%$, and the contraction decreased from $23 \%$ to $8 \%$. The decrease in the modulus of elasticity was shown on the samples after intensive plastic deformation in comparison with the initial state. Exhaustion of the plasticity and hardening of aluminum alloy EN AW 6012 was caused by intensive plastic deformation. EN AW 6012 alloy showed a significant increase in hardness HV10 in the post-ECAP state, up to 125 on an average. In its initial state, EN AW 6012 displayed hardness of about 103 (Tab. 2).

A macroscopic analysis of the samples in the initial state and after plastic deformation is shown in Figures 7 and 8 . It can be concluded that greater plastic deformation has been replaced by minimum macroscopic deformation. The fracture surface of the sample seems to be slightly rugged. The surface of the

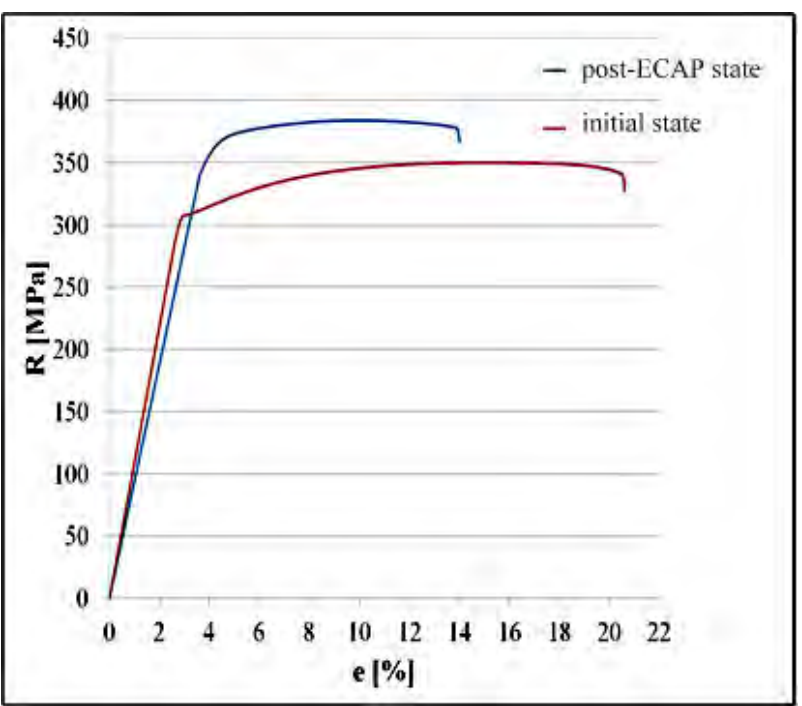

Figure 6. Dependent force of strain and elongation in the static condition of EN AW6012.

fracture on each sample of EN AW 6012 aluminium alloy was in the direction of the axial load. Figure 9 shows a detail of the fracture surface in the initial state, and Figure 10 shows the post-ECAP state.

The fracture surfaces, documented by SEM after a tensile test, are presented in (Figures 9 12). Figure 9 shows the fracture surface of EN AW 6012 in the initial state. Figure 10 shows the fracture surface of the ECAPed state of the aluminium alloy. Details of the fracture surface are shown in Figures 11 and 12 The analysis of the fracture surfaces of the investi- 


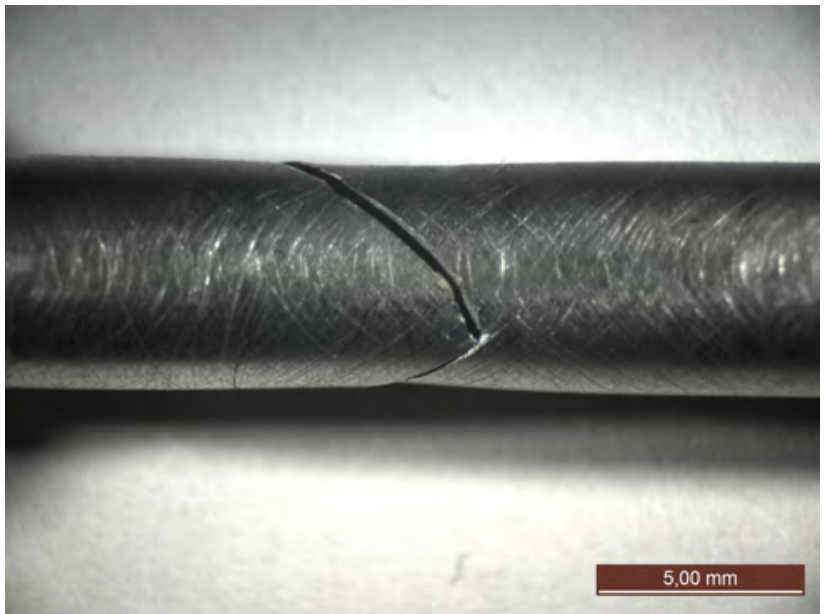

Figure 7. Fracture of EN AW 6012 alloy in pre-ECAP.

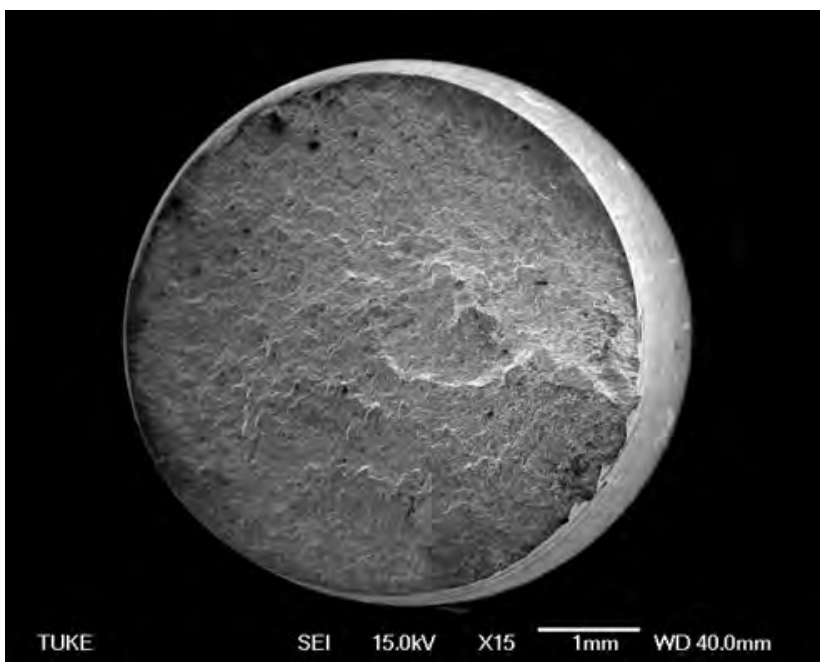

FiguRE 9. The fracture surface of EN AW 6012 in the initial state.

gated pre-ECAP and post-ECAP materials showed dominance of transcrystalline ductile fracture. The effect of plastic deformation was revealed in particle cracking for the relevant materials. During plastic deformation, particles were cracked and/or particles were divided from the interphase surface by means of cavity failure systems, which developed from the former dimples. The morphology of the fracture surface was observed as characterized dimples with local presence of striation. The shapes of the fracture surfaces of the samples are characterized by a mixed morphology, which is formed by the surfaces of the particles and the digested holes within a transgranular ductile fracture. The appearance of the surfaces of both surfaces has visible lines, which is an infringement of the guidelines. The fracture was initialized from the surface of the specimen, and the crack growth continued in the perpendicular direction of the axis of the specimen.

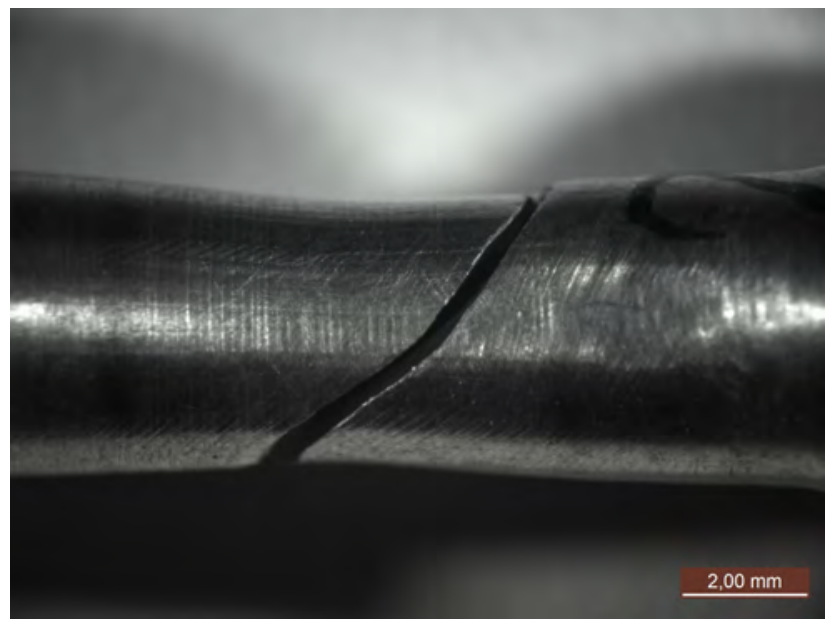

Figure 8. Fracture of EN AW 6012 alloy post-ECAP.

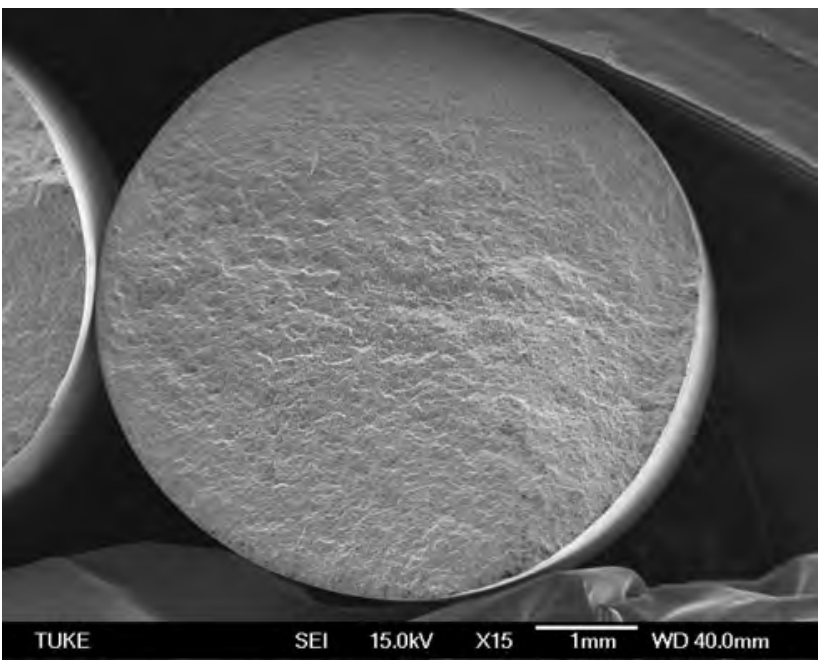

Figure 10. The fracture surface of EN AW 6012 in the post-ECAP state.

\section{Conclusions}

On the basis of our experimental work, we have drawn the following conclusions. The intensive plastic deformation carried out by ECAP technology can be summarized as follows:

- Increased strength properties: the yield strength increased by $18 \%$, and the ultimate tensile strength increased by $16 \%$.

- There was also a significant $23 \%$ increase in hardness HV10. However, the plastic characteristics decreased: the elongation decreased by $31 \%$, and the area decreased by $21 \%$.

- Due to the exhaustion of plasticity and hardening of the EN AW 6012 aluminium alloys, the samples showed a lower elasticity modulus value after the application of intensive plastic deformation.

- A macroscopic examination proved that the surface of the fracture is perpendicular to the load in the 


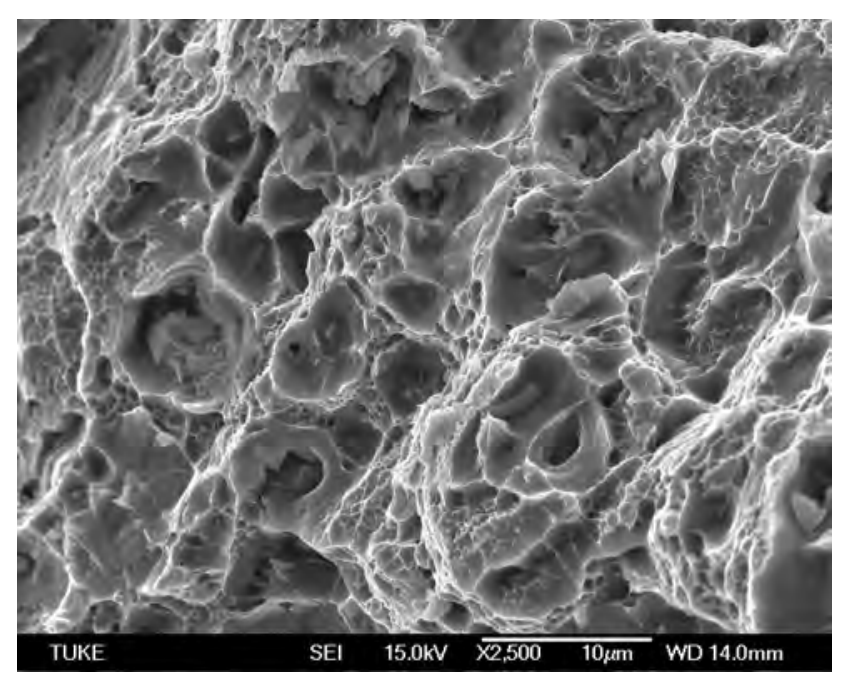

FiguRE 11. Detail of the fracture surface of EN AW 6012 in the initial state.

EN AW 6012 alloy in its initial state, and also in the ECAPed state.

- The surface fracture on the composite formed in the direction of the axial load.

- After intensive plastic deformation, shear bands can be observed on the microstructural level. They point to non-uniform deformation along the cross section of the sample. It is evident that there was deformation that led to the formation of shear bands. These shear bands developed, and led to deformation along narrow paths.

- A flat fracture with dimples and local presence of striations was observed on EN AW 6012 in both states (Figures 11 and 12). The surface was highly fractured, with a fine-grained morphology.

\section{ACKNOWLEDGEMENTS}

This study was supported by the Grant Agency of the Slovak Republic, grant project VEGA 1/0549/14.

\section{REFERENCES}

[1] Katgerman,L., Eskin, D.: Hardening, Annealing, and Aging. In.: Handbook of Aluminum. Edited by G.E. Totten, D.C. MacKenzie, New York, 1, 2003, p. 266-280, ISBN: 0-8247-0494-0

[2] Smolej, A. et al.: Influence of heat treatment on the properties of the free-cutting AlMgSiPb alloy. Journal of Materials Processing Technology, 53, 1-2, 1995, p. 373-384, DOI:10.1016/0924-0136(95)01994-P

[3] Davis, J. R.: Machining of aluminum and aluminum alloys. In.: ASM Handbook, Vol. 16. Edited by J. R. Davis, Materials Park, OHIO, ASM International, 1989, p. 761,8041989, ISBN: 978-0-87170-022-3

[4] Nejezchlebova, J. et al.: Ultrasonic detection of ductile-to-brittle transitions in free-cutting aluminum alloys. NDT \& E International, 69, 2015, p. 40-47, DOI:10.1016/j.ndteint.2014.09.007

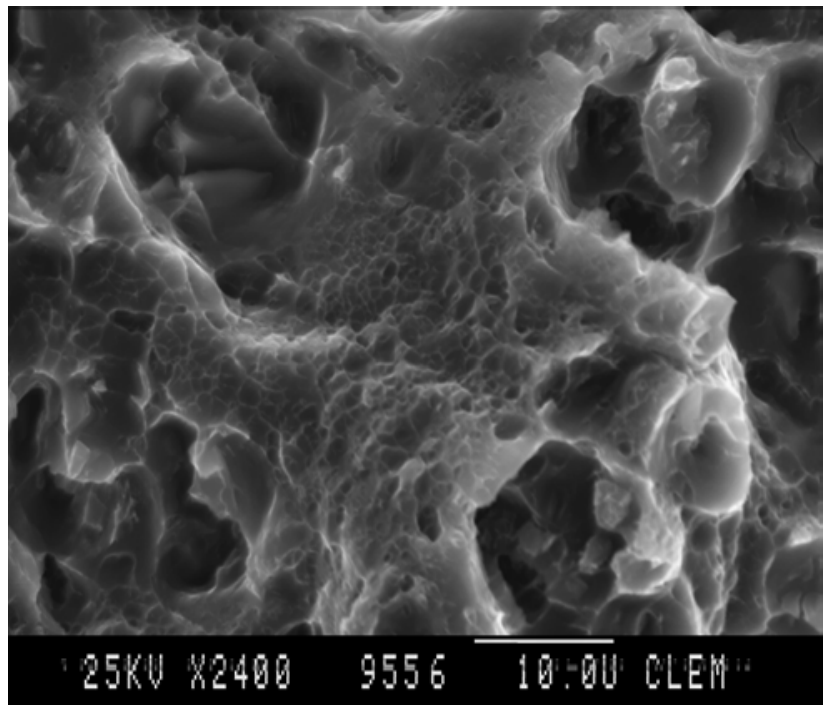

Figure 12. Detail of the fracture surface of EN AW 6012 in the post-ECAP state.

[5] De Hosson, J. T. M.: Lead induced intergranular fracture in aluminum alloy AA6262. Materials science and engineering a-Structural materials properties microstructure and processing, 361, 1-2, 2003, p. 331-337, DOI:10.1016/S0921-5093(03)00521-5

[6] Timelli, G., Bonollo, F.: Influence of tin and bismuth on machinability of lead free 6000 series aluminium alloys. Materials Science and Technology, 27, 1, 2011, p. 291-299, DOI:10.1179/026708309X12595712305799

[7] Koch, A., Antrekowitsch, H.: Free-Cutting Aluminium Alloys with Tin as Substitution for Lead. BHM Bergund Hüttenmännische Monatshefte, 153, 7, 2008, p. 278-281, DOI:10.1007/s00501-008-0390-5

[8] Kopač, J. et al.: Strategy of Machinability of Aluminium Alloys for Free Cutting. Proceedings of the Thirtieth International MATADOR Conference, 1993, p. 151-156, DOI:10.1007/978-1-349-13255-3_20

[9] Davis, J. R.: Physical Metallurgy. In ASM Specialty Handbook: Aluminum and Aluminum Alloys. Edited by J. R. Davis, Publisher: ASM International, OHIO, 1993, p. 31-47, ISBN: 978-0-87170-496-2

[10] Sokolovič, M., Kopač, J., Smolej, A.: Model of quality management in development of new free-cutting Al-alloy. Journal of Achievements in Materials and Manufacturing Engineering, 19, 2, 2006, p. 92-98

[11] Segal, V. M.: Materials processing by simple shear. Materials Science and Engineering, 197, 2, 1995, p. 157-164, DOI:10.1016/0921-5093(95)09705-8

[12] Furukawa, M. et al.: Processing of metals by equalchannel angular pressing. Journal of Materials Science, 36, 2001, p. 2835-2843, DOI:10.1023/A:1017932417043

[13] Furukawa, M., Horita, Z., Langdon, T. G.: Developing ultrafine grain sizes using severe plastic deformation. Advanced Engineering Materials, 3, 2001, p. $121-125$, DOI: $10.1002 / 1527-$ 2648(200103)3:3<121::AID-ADEM121>3.0.CO;2-V 
[14] Horita, Z. et al.: Improvement of Mechanical Properties for Al Alloys Using Equal-Channel Angular Pressing. Journal of Materials Processing Technology, 117, 2001, p. 288-292, DOI:10.1016/S0924-0136(01)00783-X

[15] Islamgaliev, R. K. et al.: Characteristics of superplasticity in an ultrafine-grained Aluminum Alloy processed by ECA pressing, Scripta Materialia, 49, 2003, p. 467-472, DOI:10.1016/S1359-6462(03)00291-4

[16] Kvačkaj, T. et al.: Ultra Fine Structure and Properties Formation of EN AW 6082 Alloy. High Temperature Materials and Processes, 27, 3, 2008, p. 193-202, DOI:10.1515/HTMP.2008.27.3.193

[17] Nurislamova, G. et al.: Nanostructure and related mechanical properties of an Al-Mg-Si alloy processed by severe plastic deformation. Philosophical Magazine Letters, 88, 6, 2008, p. 459-466, DOI:10.1080/09500830802186938

[18] Khan, A. S., Meredith, C. S.: Thermomechanical response of $\mathrm{Al} 6061$ with and without equal channel angular pressing (ECAP). International Journal of Plasticity, 26, 2010, p.189-203, DOI:10.1016/j.ijplas.2009.07.002

[19] Huang, Y., Prangnell, P.B.: Continuous frictional angular extrusion and its application in the production of ultrafine-grained sheet metals. Scripta Materialia, 56, 2007, p. 333-336, DOI:10.1016/j.scriptamat.2006.11.011

[20] Cherukuri, B., Nedkova, T.S., Srinivasan, R.: A comparison of the properties of SPD-processed AA6061 by equal-channel angular pressing, multi-axial compressions/forgings and accumulative roll bonding. Material Science and Engineering A, 410, 2005, p. 394-397, DOI:10.1016/j.msea.2005.08.024

[21] Hockauf, K. et al.: Improvement of strength and ductility for a 6056 aluminum alloy achieved by a combination of equal-channel angular pressing and aging treatment. Journal of Materials Science, 45, 2010, p. 4754-4760, DOI:10.1007/s10853-010-4544-y
[22] Kim, W. J. et al.: Optimization of strength and ductility of $2024 \mathrm{Al}$ by equal channel angular pressing (ECAP) and post-ECAP aging. Scripta Materialia, 49, 4, 2003, p. 333-338, DOI:10.1016/S1359-6462(03)00260-4

[23] Murashkin, M. Y.: Strength of Commercial Aluminum Alloys After Equal Channel Angular Pressing and PostECAP Processing. Solid State Phenomena, 114, 2006, p. 91-96, DOI:10.4028/www.scientific.net/SSP.114.91

[24] Kim, J. K., Kima, W. J.: Effect of Post-ECAP Aging on Mechanical Properties of Age-Hardenable Aluminum Alloys. Solid State Phenomena, 124-126, 2007, p. 14371440, DOI:10.4028/www.scientific.net/SSP.124-126.1437

[25] Manping Liu et al.: DSC analyses of static and dynamic precipitation of an $\mathrm{Al}-\mathrm{Mg}-\mathrm{Si}-\mathrm{Cu}$ aluminum alloy. Progress in Natural Science: Materials International, 25, 2, 2015, p. 151-158, DOI:10.1016/j.pnsc.2015.02.004

[26] ISO 6507-1: Metallic materials - Vickers hardness test - Part 1: Test method, 2005

[27] Callister, W., D. Jr., Rethwisch, D.G.: Chapter 6 / Mechanical Properties of Metals. In.: Materials Science and Engineering an Introduction, Seventh edition, John Wiley \& Sons, New York, 2007, p. 133-165, ISBN: 978-0-471-73696-7

[28] ISO 6892-1: Metallic materials - Tensile testing Part 1: Method of test at room temperature, 2009

[29] Miháliková, M., Német, M., Vojtko, M.: Impact of strain rate on microalloyed steel sheet fracturing. Acta Polytechnica, 54, 4, 2014, p. 281-28, DOI:10.14311/AP.2014.54.0281

[30] Timelli, G., Bonollo, F.: Influence of tin and bismuth on machinability of lead free 6000 series aluminium alloys. Materials Science and Technology, 7, 1, 2011, p. 291-299, DOI:10.1179/026708309X12595712305799 